\begin{tabular}{|c|c|c|c|c|c|}
\hline JRL & Vol. 12 & No. 2 & Hal : $155-174$ & $\begin{array}{c}\text { Jakarta, } \\
\text { Desember } 2019\end{array}$ & $\begin{array}{c}\text { p-ISSN : 2085.38616 } \\
\text { e-ISSN : 2580-0442 }\end{array}$ \\
\hline
\end{tabular}

\title{
STUDI LINGKUNGAN TEMPAT PEMROSESAN AKHIR SAMPAH GALUGA KECAMATAN CIBUNGBULANG KABUPATEN BOGOR PROVINSI JAWA BARAT
}

\author{
Fuzi Suciati, Dwindrata B. Aviantara \\ Pusat Teknologi Lingkungan - BPPT \\ Gd. 820 Geostech PUSPIPTEK Serpong, 15314, Provinsi Banten \\ Email : fuzi.suciati@gmail.com
}

\begin{abstract}
Abstrak
Tempat pemrosesan akhir (TPA) sampah Galuga merupakan areal controlled landfill untuk sampah domestik penduduk Kota dan Kabupaten Bogor. Areal seluas 54 ha tersebut 92\% diperuntukkan bagi sampah domestik Kota Bogor. Sebanyak 500 ton/hari sampah domestik Kota Bogor serta 600 ton/hari sampah domestik Kabupaten Bogor dibuang pada fasilitas penimbusan akhir tersebut. Fasilitas TPA Galuga yang telah beroperasi lebih dari 30 tahun tersebut dilengkapi pula dengan unit proses pengomposan sampah open windrow. Namun laju perolehan produk akhir kompos belum mampu mengimbangi laju penambahan sampah domestik yang masuk ke areal tersebut. Dari sekitar 1100 ton per hari sampah yang masuk ke TPA galuga sekitar $250-300$ ton per hari sampah yang berupa plastik maupun kertas dapat disisihkan oleh pemulung. Walaupun TPA Galuga merupakan controlled landfill namun belum terkelola dengan baik. Hal tersebut menimbulkan persoalan lingkungan bau sampah serta mutu lindi yang fluktuatif. Terobosan teknologi tampaknya diperlukan untuk menanggulangi persoalan sampah di TPA Galuga.
\end{abstract}

kata kunci : sampah domestik, tempat pemrosesan akhir, penimbusan akhir, kualitas lingkungan

Studi Lingkungan Tempat.. JRL, Vol. 12 No. 2 - Desember 2019: 155 - 174 


\title{
ENVIRONMENTAL STUDY OF GALUGA \\ MUNICIPAL GARBAGE FINAL DISPOSAL SITE AT \\ CIBUNGBULANG DISTRICT BOGOR REGENCY PROVINCE OF WEST JAVA
}

\begin{abstract}
Galuga final disposal site (TPA) is a specified area for controlled landfill of municipal garbage collected from Bogor City and Bogor Regency. 92\% of the 54 hectares land is dedicated to Bogor City. Around 500 tons/d municipal garbage of Bogor city and 600 tons/d of Bogor Regency are dumped in the TPA. The 30 years (at least) operated TPA is also equipped with open windrow composting facilty. However, the obtained product could not counter balance the increasing volume of municipal garbage. From 1100 tons/d municipal garbage entering TPA Galuga only 250 - 300 tons/d capable of being sorted by scavengers. Even though TPA Galuga is a controlled landfill, however, it has not been managed appropriately. This situation created environmental problems such as bad odor and fluctuated quality of leachate. Technology breakthrough is needed to overcome a huge pile of domestic garbage in TPA Galuga.
\end{abstract}

keywords : municipal garbage, final disposal site, landfill, environmental quality 


\section{PENDAHULUAN}

Seiring dengan peningkatan populasi penduduk akan dihasilkan sampah padat yang dikelola berdasarkan Undang-Undang Nomor 18 tahun 2008 tentang Pengelolaan Sampah serta peraturan turunannya yaitu Peraturan Menteri Dalam Negeri Nomor 33 Tahun 2010 tentang Pedoman Pengelolaan Sampah. Tempat Pemrosesan Akhir (TPA) Galuga yang berlokasi berada di Desa Galuga, Kecamatan Cibungbulang, Kabupaten Bogor, Provinsi Jawa Barat merupakan sarana pengelolaan limbah padat domestik bagi Kota dan Kabupaten Bogor. Secara administratif kewilayahan lokasi TPA Galuga berada dalam pengelolaan Pemerintah Kabupaten Bogor. Namun secara operasional TPA Galuga berada dalam pengelolaan Pemerintah Kota Bogor. Dari luasan 52 ha lahan TPA Galuga sekitar 48 ha (92\%) merupakan areal yang diperuntukkan bagi pembuangan sampah yang bersumber dari penduduk Kota Bogor. Sedangkan lahan seluas 4 ha $(8 \%)$ diperuntukkan bagi pembuangan sampah yang bersumber dari penduduk Kabupaten Bogor (Yusuf 2017). Sistem demikian merupakan sumber conflict of interest antara Pemerintah Kota Bogor dengan Pemerintah Kabupaten Bogor. Situasi seperti ini serupa dengan permasalahan pada TPA Bantar Gebang di mana Pemerintah Provinsi DKI Jakarta membuang sampah di lahan TPA tersebut yang secara administratif berada di wilayah Kota Bekasi Provinsi Jawa Barat. Salah satu penyebab dari timbulnya permasalahan tersebut adalah pemekaran wilayah serta undang-undang mengenai otonomi daerah. Perjanjian pengelolaan TPA Galuga antara Pemerintah Kota Bogor dengan Pemerintah Kabupaten Bogor berlaku selama 5 (lima) tahun sehingga untuk keberlangsungan pengelolaan TPA tersebut memerlukan perpanjangan perjanjian setiap 5 tahun (Afifah 2018).

Penetapan TPA Galuga sebagai tempat pemrosesan akhir sampah sebenarnya telah diawali pada tahun 1986 (Yusuf 2017, Afifah 2018), yakni tahun pembangunan atau persiapan lahan untuk pengelolaan sampah, namun mulai beroperasi pada tahun 1992 (Purba 2016). Operasional TPA Galuga adalah dua tahun sebelum diterbitkannya persyaratan atau peraturan Standar Nasional Indonesia SNI 03-32411994 tentang Tata Cara Pemilihan Lokasi Tempat Pembuangan Akhir Sampah. Meski demikian, legalitas areal TPA Galuga telah sesuai dengan Rencana Tata Ruang Wilayah (RTRW) Kabupaten Bogor tahun 2002 yang ditetapkan oleh Badan Perencanaan Daerah Kabupaten Bogor. Selain itu juga diperkuat oleh Keputusan Bupati Bogor Nomor $591 / 131 / \mathrm{kpts} /$ Huk $/ 2002$ tentang Penetapan Lokasi untuk Tempat Pemrosesan Akhir (TPA) Sampah (Yusuf 2017). Citra satetit SPOT (Satellite Pour l'Observtion de la Terre)/CNES google map areal TPA Galuga serta peta tata guna lahan Bakosurtanal (Badan Koordinasi Survey dan Pemetaan Nasional) pada dan sekitar areal TPA tersebut ditunjukkan pada Gambar 2 dan Gambar 3 (Desmawati 2010).

Sebagaimana tampak pada Gambar 1 lokasi TPA Galuga 
berada pada kontur lahan di ketinggian dalam kisaran 214 - 273 $\mathrm{m} \mathrm{dpl} \mathrm{(di} \mathrm{atas} \mathrm{permukaan} \mathrm{laut)}$ dengan lereng yang mengarah ke utara. Dengan demikian air larian (run off) akan memiliki kecenderungan untuk bergerak ke arah utara pula. Dari peta tataguna lahan tersebut tampak bahwa di sebelah utara TPA Galuga berbatasan dengan permukiman penduduk, kebun/perkebunan dan persawahan. Di sebelah selatan berbatasan dengan semak belukar yang merupakan kaki atau landaian Gunung Galuga. Sedangkan di sebelah timur dan barat keduanya berbatasan dengan areal kebun atau perkebunan. Namun citra satelit $2019 \quad$ Googlemap menunjukkan bahwa sebelah barat telah ada permukiman meski jumlahnya tidak sebanyak yang terdapat di permukiman sebelah Utara. Pada saat survei lapangan di sekitar TPA Galuga dilaksanakan permukiman sebelah barat tersebut tampaknya adalah para pendatang yang bekerja sebagai pemulung di areal TPA Galuga maupun yang memiliki usaha sejenis warung di sekitarnya.

Areal TPA Galuga memiliki dua pintu di mana kendaraan pengangkut sampah dapat masuk maupun keluar. Pintu yang pertama terdapat di sebelah selatan berdekatan dengan pertigaan Jalan Galuga. Pintu ini merupakan akses bagi kendaraan pengangkut sampah yang dikelola oleh Pemerintah Kabupaten Bogor. Sedangkan pintu kedua yang berada di sebelah barat, berdekatan dengan areal pengomposan, merupakan akses bagi kendaraan pengangkut sampah yang dikelola oleh Pemerintah Kota Bogor. Kendaraan angkut sampah yang digunakan adalah tipikal truk pengangkut sampah sebagaimana disajikan pada Gambar 1. Kapasitas rata-rata tipikal truk pengangkut sampah adalah $6 \mathrm{~m}^{3}$. Informasi yang diperoleh dari pengelola TPA Galuga bobot sampah per hari yang masuk dari wilayah Kota Bogor sebesar 400 - 500 ton sedangkan dari wilayah Kabupaten Bogor sebesar 600 ton. Informasi ini sangat kontras dengan kenyataan bahwa areal TPA Galuga yang diperuntukkan bagi pengelolaan sampah Kabupaten Bogor hanya 3,8 ha dari 52 ha luasan lahan TPA Galuga. Kecilnya bagian luasan Iahan tersebut mungkin adalah salah satu penyebab terjadinya antrian panjang yang akan masuk melalui pintu TPA sebelah selatan.

Teknis operasional layanan angkutan sampah domestik yang dikelola oleh Pemerintah Kota Bogor meliputi daerah permukiman, komersial, fasilitas umum serta jalan. Data jumlah rit, bobot serta volume sampah terangkut tiap bulan untuk tahun 2016 disajikan pada Tabel 1 (Dinas Lingkungan Hidup Kota Bogor 2019)

Studi lingkungan TPA Galuga memiliki maksud menelaah praktek pengelolaan limbah padat domestik, khususnya Kota Bogor, dengan tujuan mendapatkan gambaran dampak maupun manfaat keberadaan TPA Galuga. Untuk itu dilakukan sampling air lindi (leachate), air permukaan serta tanah di sekitar areal TPA Galuga. 


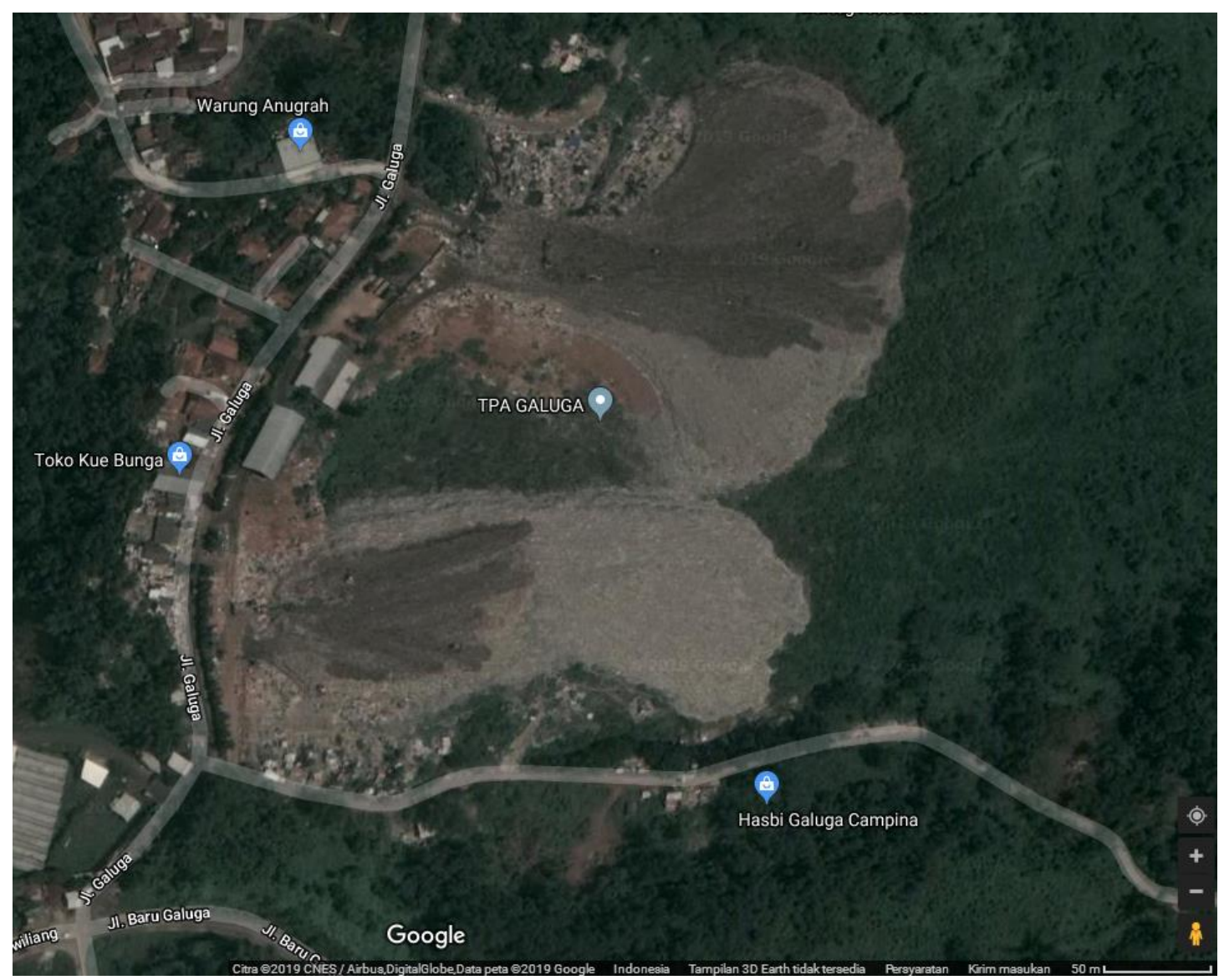

Gambar 1. Citra Satelit 2019 SPOT/CNES Googlemap Areal TPA Galuga

(Sumber: Desmawati 2010)

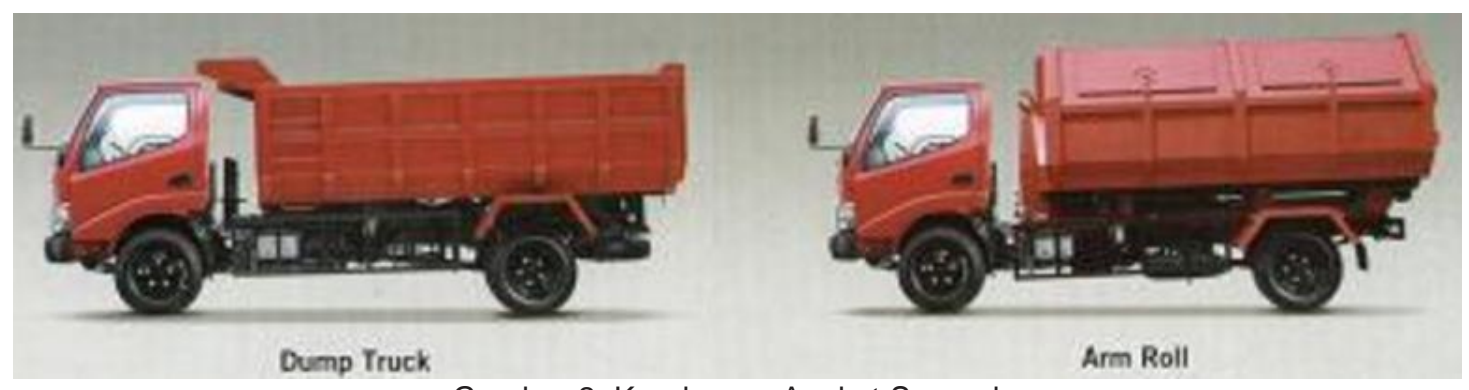

Gambar 2. Kendaraan Angkut Sampah 


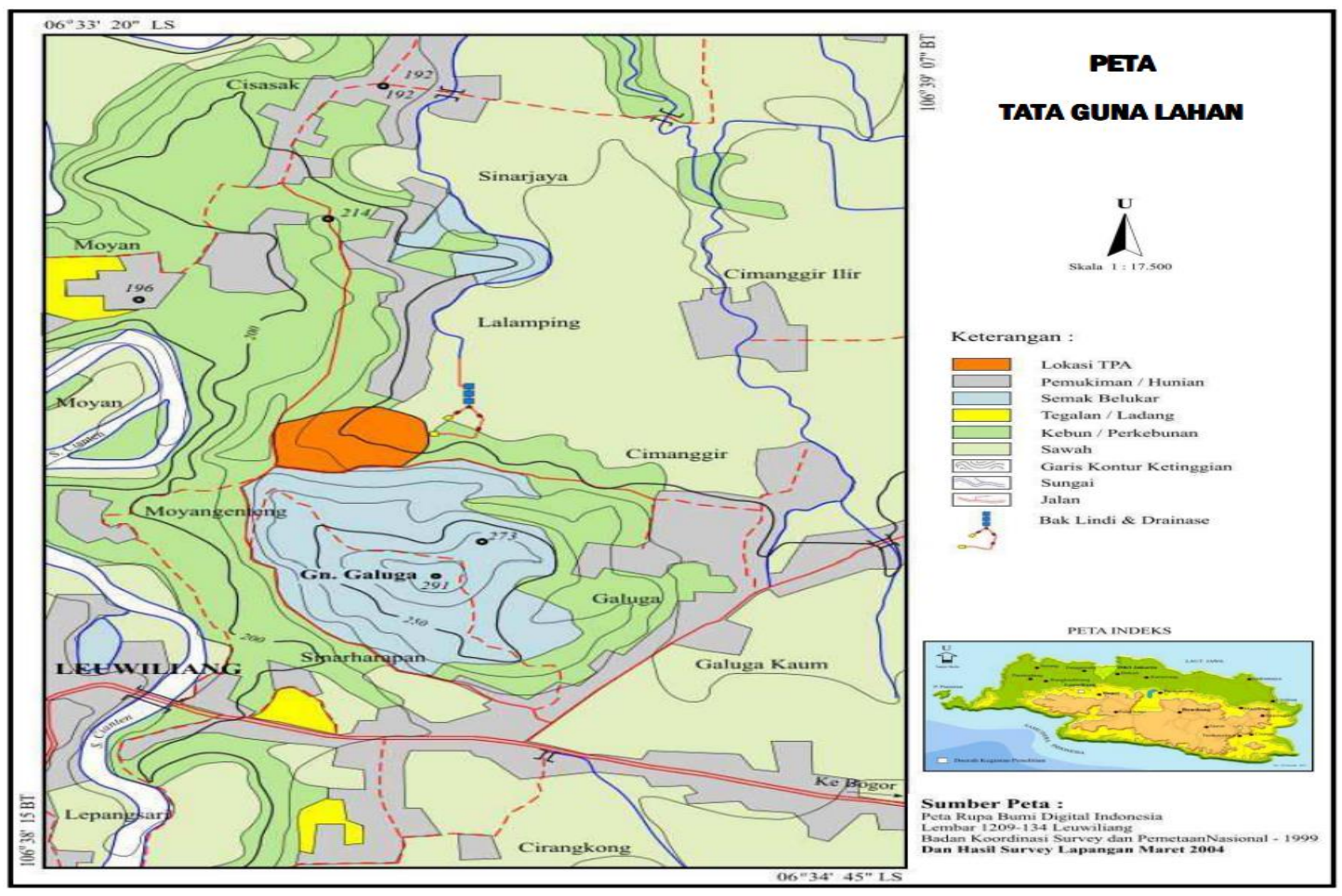

Gambar 3. Tata Guna Lahan Areal Sekitar TPA Galuga (Sumber: Desmawati 2010)

Tabel 1. Data Sampah Terangkut Kota Bogor (Sumber: Dinas Lingkungan Hidup Kota Bogor 2019)

\begin{tabular}{|c|c|c|c|c|c|}
\hline \multirow{2}{*}{ No } & \multirow{2}{*}{ Bulan } & \multicolumn{3}{|c|}{ Jumlah } & Tempat Pembuangan \\
\cline { 5 - 6 } & & RIT/BULAN & TONASE/Bulan & KUBIKASI/Bulan & \\
\hline 1 & $2016-01-01$ & 7,147 & $54,953.0$ & $16,485.9$ & TPA GALUGA \\
\hline 2 & $2016-02-01$ & 7,355 & $56,305.0$ & $16,891.5$ & TPA GALUGA \\
\hline 3 & $2016-03-01$ & 8,028 & $61,632.0$ & $18,489.6$ & TPA GALUGA \\
\hline 4 & $2016-04-01$ & 7,764 & 59,624 & $17,887.2$ & TPA GALUGA \\
\hline 5 & $2016-06-01$ & 7,780 & $59,527.0$ & $17,859.1$ & TPA GALUGA \\
\hline 6 & $2016-07-01$ & 8,070 & $61,968.0$ & 18,590 & TPA GALUGA \\
\hline 7 & $2016-08-01$ & 8,012 & $61,986.0$ & 18,595 & TPA GALUGA \\
\hline 8 & $2016-09-01$ & 7,760 & $59,951.0$ & 17,985 & TPA GALUGA \\
\hline 9 & $2016-10-01$ & 8,075 & $61,940.0$ & $18,582.0$ & TPA GALUGA \\
\hline 10 & $2016-11-01$ & 7,814 & $60,009.0$ & $18,002.7$ & TPA GALUGA \\
\hline 11 & $2016-12-01$ & 8,052 & $61,820.0$ & $18,546.0$ & TPA GALUGA \\
\hline 12 & $2016-05-01$ & 7,966 & $61,877.0$ & $18,563.1$ & TP GALUGA \\
\hline
\end{tabular}




\section{TUJUAN}

Tujuan dari pelaksanaan studi lingkungan ini adalah untuk mendapatkan gambaran umum kondisi terkini TPA Galuga, mendapatkan sample lingkungan sekitar TPA Galuga (air lindi (leachate), air permukaan dan tanah) serta melakukan interpretasi kualitas lingkungan berdasarkan hasil pengukuran laboratorium terhadap sampling lingkungan.

\section{METODE}

Secara garis besar metode yang dilaksanakan dalam survei ini disajikan dalam bagan alir (flow chart) sebagaimana tampak pada Gambar 4. Pada bagian perencanaan kegiatan ditetapkan rancangan tanggal dan durasi kunjungan, rencana survei, penyediaan alat dan kendaraan untuk survei, penetapan jumlah sampel yang akan diambil (air dan tanah), serta penyiapan surat ijin survei. Selanjutnya pada bagian administrasi dilakukan pemrosesan ijin Dinas Lingkungan Hidup Kota Bogor selaku pengelola TPA Galuga. Pada saat survei dilakukan pengumpulan data lapangan serta sampling untuk mendapatkan contoh air lindi, air permukaan serta tanah. Ketiga matriks lingkungan tersebut akan digunakan untuk melakukan evaluasi kinerja pengolahan air lindi TPA Galuga serta kualitas lingkungan sekitar di mana TPA Galuga beroperasi. Evaluasi tersebut didasarkan atas hasil pemeriksaan laboratorium terhadap ketiga jenis matriks lingkungan yang dikumpulkan tersebut. Untuk pemeriksaan laboratorium mengikuti prosedur penetapan sejumlah parameter di antaranya adalah kebutuhan oksigen biologik (biological oxygen demand atau BOD), kebutuhan oksigen kimiawi (chemical oxygen demand atau (COD), klorin bebas (free chlorine) serta sejumlah logam berat sebagaimana diuraikan dalam dokumen Modul Praktikum Teknologi Limbah Padat dan B3 (Indrasti dkk. 2019). Beberapa parameter lingkungan seperti konsentrasi keasaman $(\mathrm{pH})$, suhu dan oksigen terlarut (dissolved oxygen atau DO) dilakukan pengukuran secara langsung di lapangan dengan menggunakan portable tool seperti pH meter dan DO meter. Tabel 2 menyajikan portable tool yang lazim digunakan dalam sampling matriks lingkungan.

Terkait dengan penilaian kinerja instalasi pengolahan air limbah (IPAL) TPA Galuga maka diambil air lindi sebelum dan setelah proses pengolahan air lindi tersebut. Adapun baku mutu yang digunakan mengacu kepada Peraturan Menteri Lingkungan Hidup dan Kehutanan Nomor 59 Tahun 2016 tentang Baku Mutu Lindi Bagi Usaha dan/atau Kegiatan Tempat Pemrosesan Akhir Sampah. Sedangkan untuk evaluasi kualitas lingkungan sekitar TPA Galuga dilakukan sampling tanah serta badan air sebelum dan setelah di mana TPA Galuga beroperasi.

Selain sampling yang ditujukan untuk evaluasi kinerja IPAL dan mutu lingkungan sekitar TPA Galuga juga dilakukan pemeriksaan karakteristik sampah yang terdapat pada TPA tersebut. Pemeriksaan karakteristik sampah bertujuan mengenali tipikal komposisi sampah domestik yang 
masuk ke TPA Galuga, seperti berapa bagian sampah yang merupakan bahan organik, kertas serta plastik. Guna memperkaya informasi terkait dengan TPA Galuga maka pada saat survei juga dilakukan wawancara serta pengisian kuesioner kepada responden pengelola TPA Galuga, pemulung, serta penduduk sekitar TPA Galuga.

Tabel 2. Contoh Portable Tool untuk Keperluan sampling Matriks Lingkungan

Soil auger
2 Nama alat
$\begin{aligned} & \text { van Dorn Tube } \\ & \text { Ponalyser } \\ & \text { Potale water }\end{aligned}$

\section{HASIL PENGAMATAN, PENGUKURAN DAN PEMBAHASAN}

Survei kondisi lingkungan TPA Galuga dilaksanakan pada bulan Februari 2019. Dari keterangan yang disampaikan oleh pihak pengelola TPA Galuga, sampah Kota Bogor yang masuk ke TPA Galuga berada dalam kisaran 400 - 500 ton/hari. Sedangkan sampah domestik yang berasal dari Kabupaten Bogor lebih kurang adalah 600 ton/hari. Operasi kendaraan truk pengangkut sampah, baik yang dikelola oleh Pemerintah Kota Bogor maupun Pemerintah Kabupaten Bogor, adalah dari jam 05:00 sampai dengan 17:00. Perbedaan pengelolaan armada truk pengangkut sampah Kota Bogor dengan Kabupaten Bogor adalah 


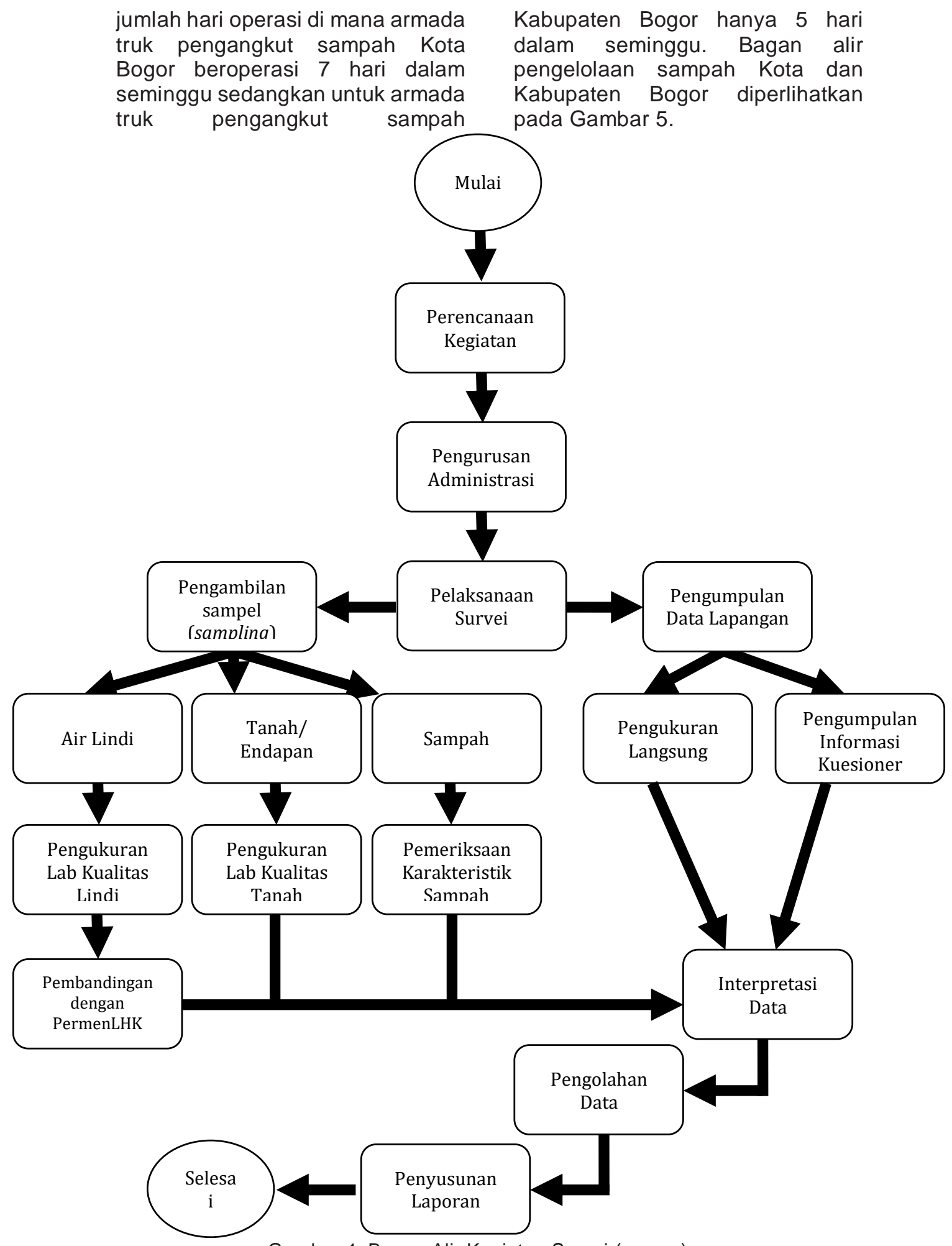

Gambar 4. Bagan Alir Kegiatan Survei (survey) 


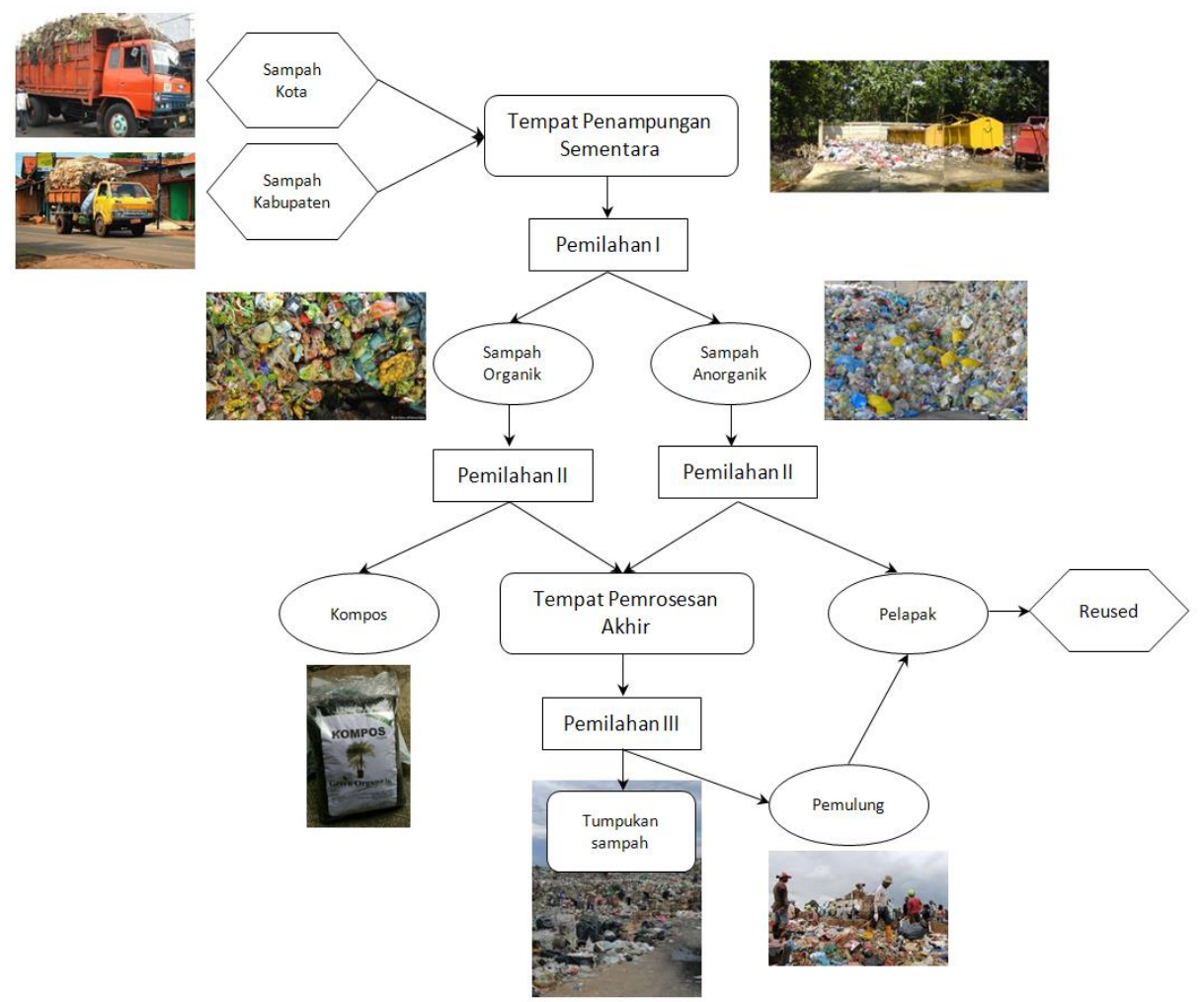

Gambar 5. Bagan Alir Pengelolaan Sampah Kota dan Kabupaten Bogor

Seperti tampak pada bagan alir Gambar 5 di atas, sampah Kota dan Kabupaten Bogor diangkut dengan kendaraan truk sampah untuk ditempatkan pada tempat penampungan sementara (TPS) yang biasanya berupa bak arm roll. Dari TPS sering kali telah terjadi pemilahan oleh pemulung jalanan sehingga sampah anorganik yang memiliki nilai jual diambil untuk kemudian dijual kepada pelapak (pengepul). Dari TPS sampah kemudian diangkut ke TPA Galuga di mana pemilahan lebih lanjut dilakukan. Sebagian sampah organik akan dikomposkan sedangkan anorganik bernilai jual diambil oleh pemulung TPA Galuga untuk kemudian juga dijual ke pelapak.

Pada saat melakukan tinjauan lapangan, sebagaimana dapat dilihat pada Gambar 6, tampak bahwa sampah yang terdapat di TPA Galuga masih dikelola dengan teknik pembuangan terbuka (open dumping) walaupun pengelola TPA menyatakan bahwa teknik yang digunakan adalah pengurugan terkendali (controlled landfill). Hal ini dikarenakan pengurugan dengan tanah yang dilakukan oleh 
pengelola TPA Galuga adalah sebanyak 4 (empat) kali dalam setahun, atau rata-rata dilakukan pengurugan setiap 3 bulan sekali. Sedangkan untuk teknik controlled landfill pengurugan dilakukan setiap $5-7$ hari sesuai dengan daur hidup (life cycle) lalat alih-alih pengurugan setiap hari sebagaimana persyaratan pengelolaan sampah dengan teknik sanitary landfill (Damanhuri \& Padmi 2010). Oleh sebab itu tidaklah mengherankan jika aroma busuk sampah begitu menyengat di areal sekitar TPA Galuga. Sebagaimana telah ditetapkan oleh Pemerintah Indonesia bahwa sejak tahun 2013 pengelolaan sampah dengan sistem open dumping adalah dilarang sesuai dengan Pasal 29 ayat 1 Undang-Undang Nomor 18 Tahun 2018 tentang Pengelolaan Sampah. Lebih lanjut dalam Pasal 44 dinyatakan bahwa:

a. Pemerintah daerah harus membuat perencanaan penutupan tempat pemrosesan akhir sampah yang menggunakan sistem pembuangan terbuka paling lama 1 (satu) tahun terhitung sejak berlakunya UU 18/2008

b. Pemerintah daerah harus menutup tempat pemrosesan akhir sampah yang menggunakan sistem pembuangan terbuka paling lama 5 (lima) tahun terhitung sejak berlakunya UU 18/2008

Saat Undang-Undang Nomor 18 Tahun 2018 diberlakukan diperkirakan terdapat 397 dari 450 tempat pengelolaan sampah yang masih menggunakan sistem open dumping (Chaerul et al. 2007). Sedangkan yang menggunakan sistem sanitary landfill dan controlled landfill masing-masing adalah 6 dan 57 tempat pengelolaan sampah. Hal ini merupakan tantangan baik bagi pemerintah pusat maupun pemerintah daerah.

Guna mengurangi bobot sampah yang ditimbun pengelola TPA Galuga memiliki fasilitas pengomposan open windrow yang dilengkapi dengan peralatan ayak seperti terlihat pada Gambar 7. Fasilitas pengomposan tersebut mampu menghasilkan kompos sekitar 20 ton per hari. Hanya saja untuk setiap satu batch proses pengomposan memerlukan waktu sekitar 1.5 - 2 bulan sehingga fasilitas pengomposan TPA Galuga tidak menyumbang banyak terhadap pengurangan volume sampah yang dihamparkan pada areal TPA Galuga. Pengurangan cukup berarti justru disumbang oleh para pemulung yang melakukan kegiatan pemilahan di TPA Galuga, seperti ditunjukkan pada Gambar 8. Pada saat ini diperkirakan terdapat 1200 orang pemulung yang melakukan kegiatan pemilahan. Dari sekitar 1.100 ton per hari sampah yang masuk ke TPA galuga sekitar 250 - 300 ton per hari sampah yang berupa plastik maupun kertas dapat disisihkan oleh pemulung yang mana hasil pemilahan tersebut kemudian dikelompokkan berdasarkan jenis sebagaimana terlihat pada Gambar 9. 

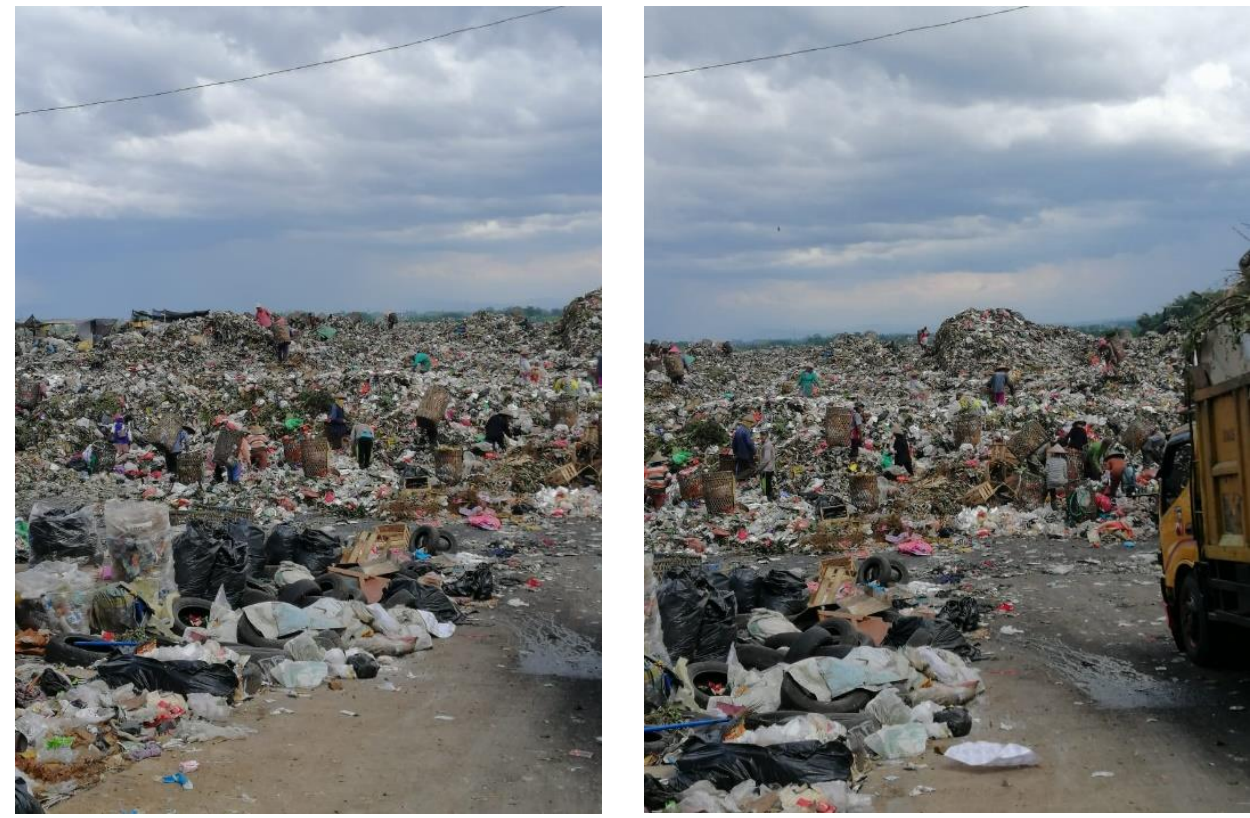

Gambar 6. Aktivitas di TPA Galuga
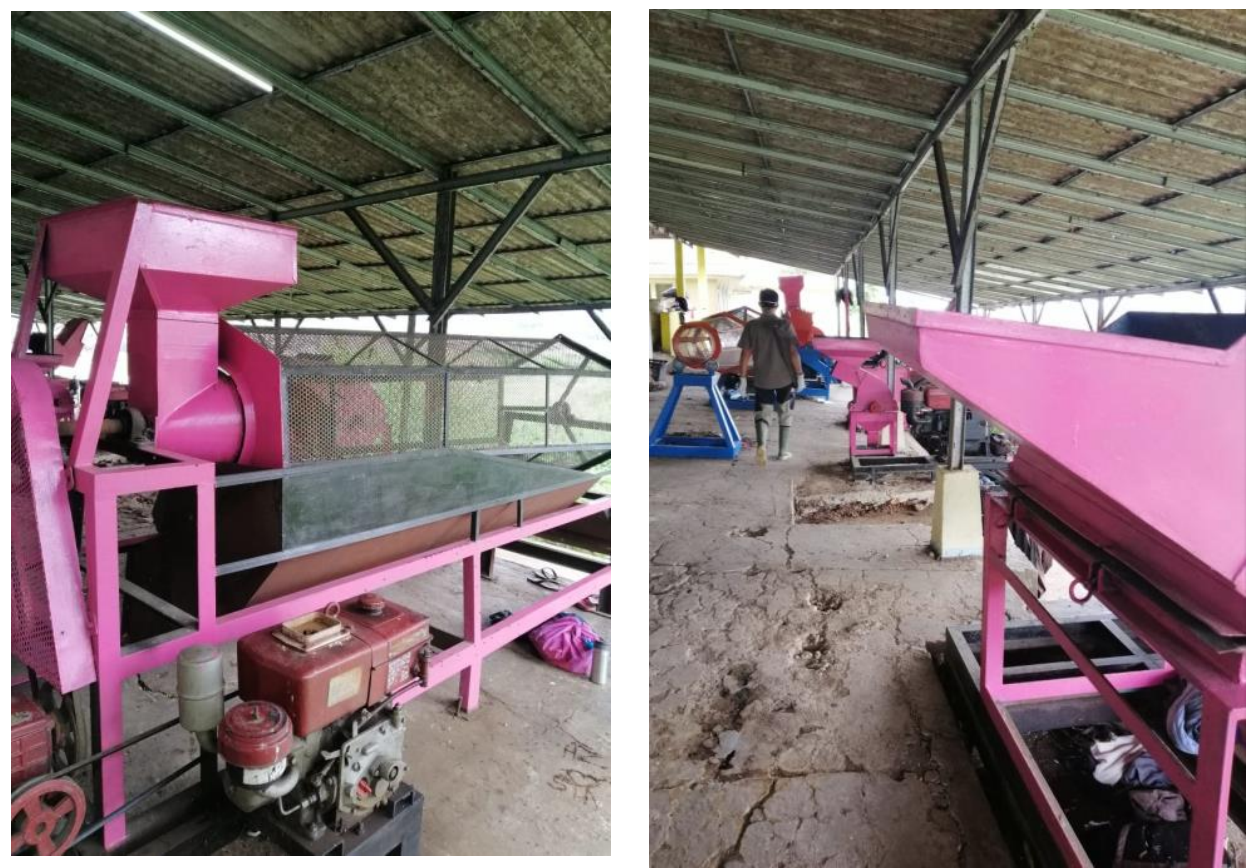

Gambar 7. Fasilitas Pengomposan TPA Galuga 


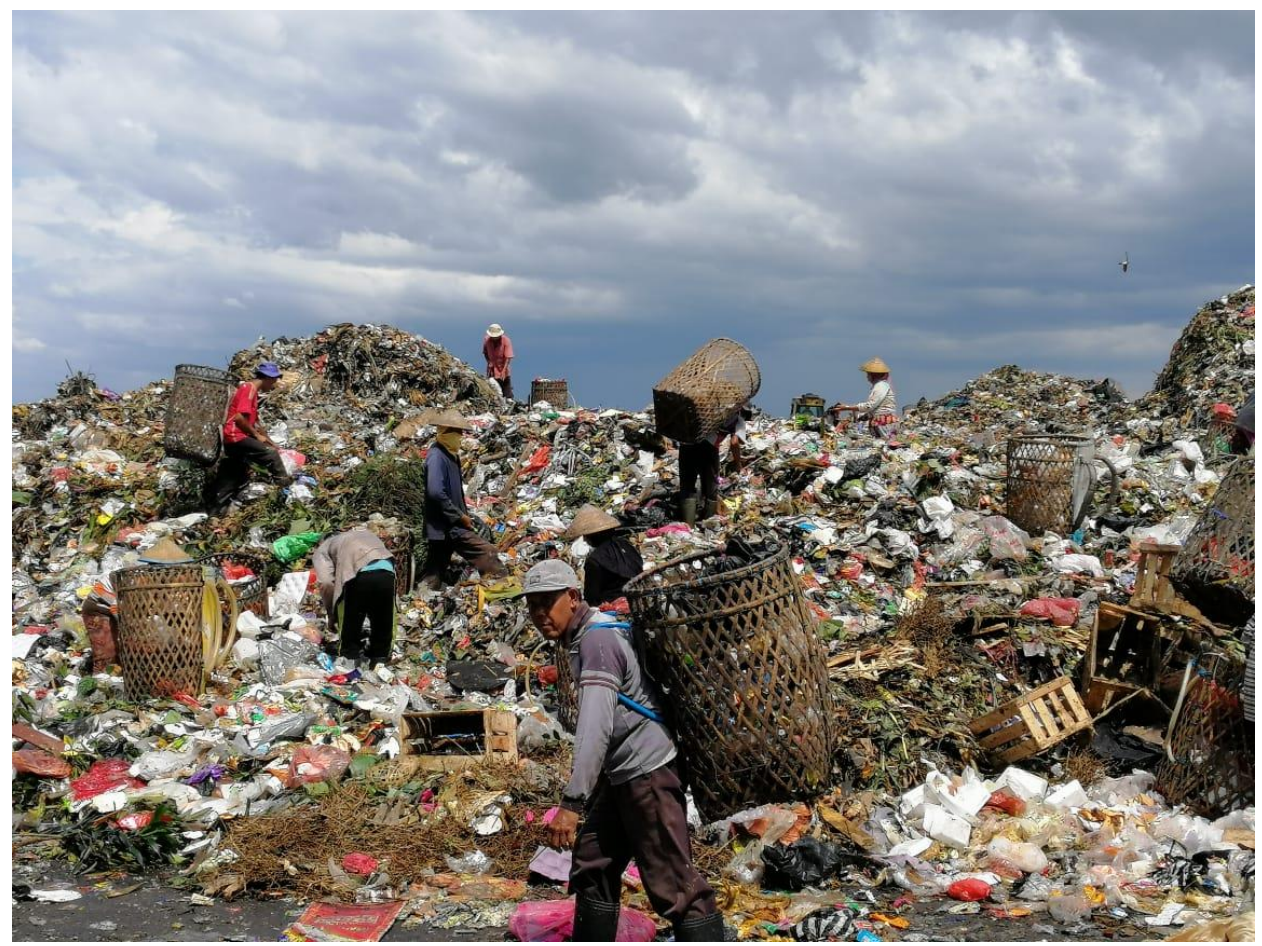

Gambar 8. Pemulung yang Melakukan Pemilahan di TPA Galuga

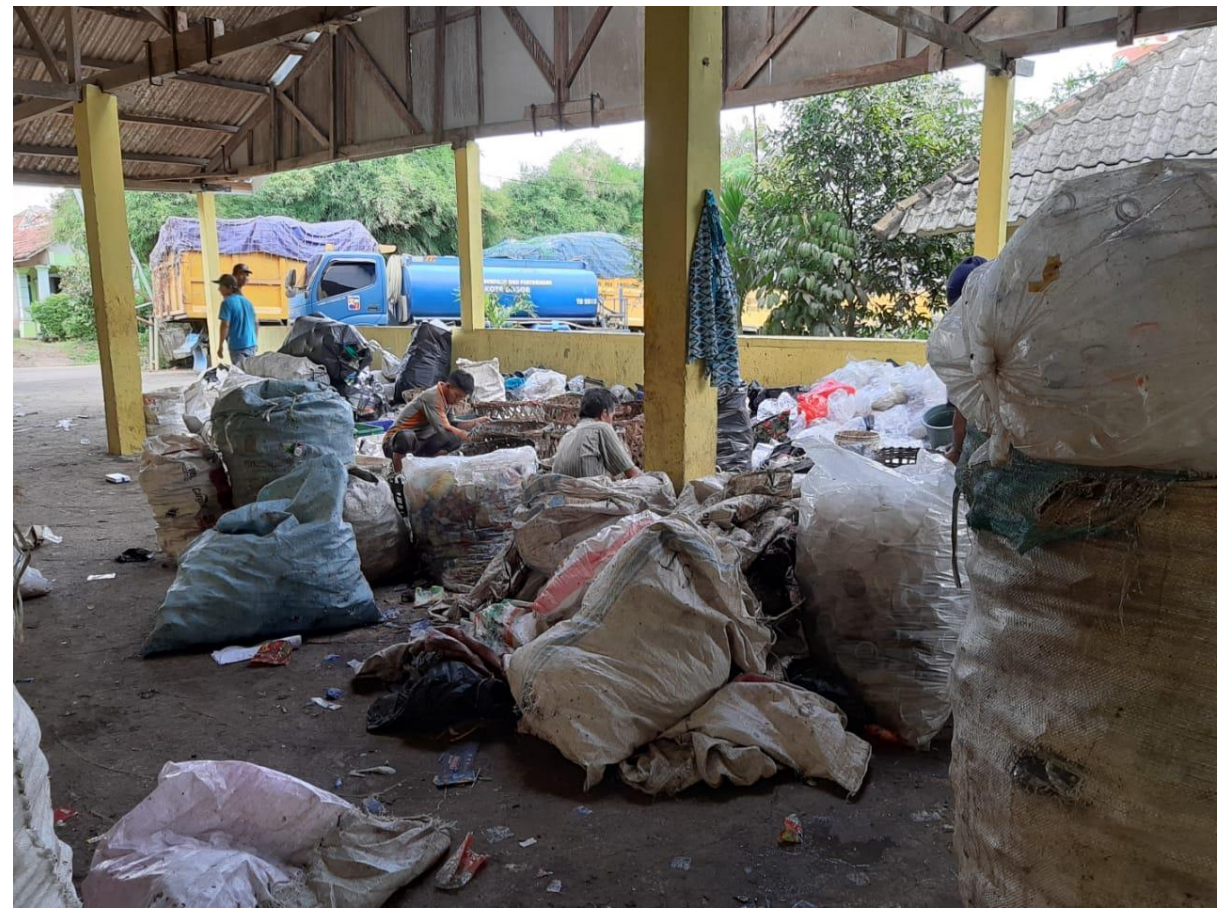

Gambar 9. Pemulung Melakukan Klasifikasi Hasil Pemilahan di TPA Galuga 


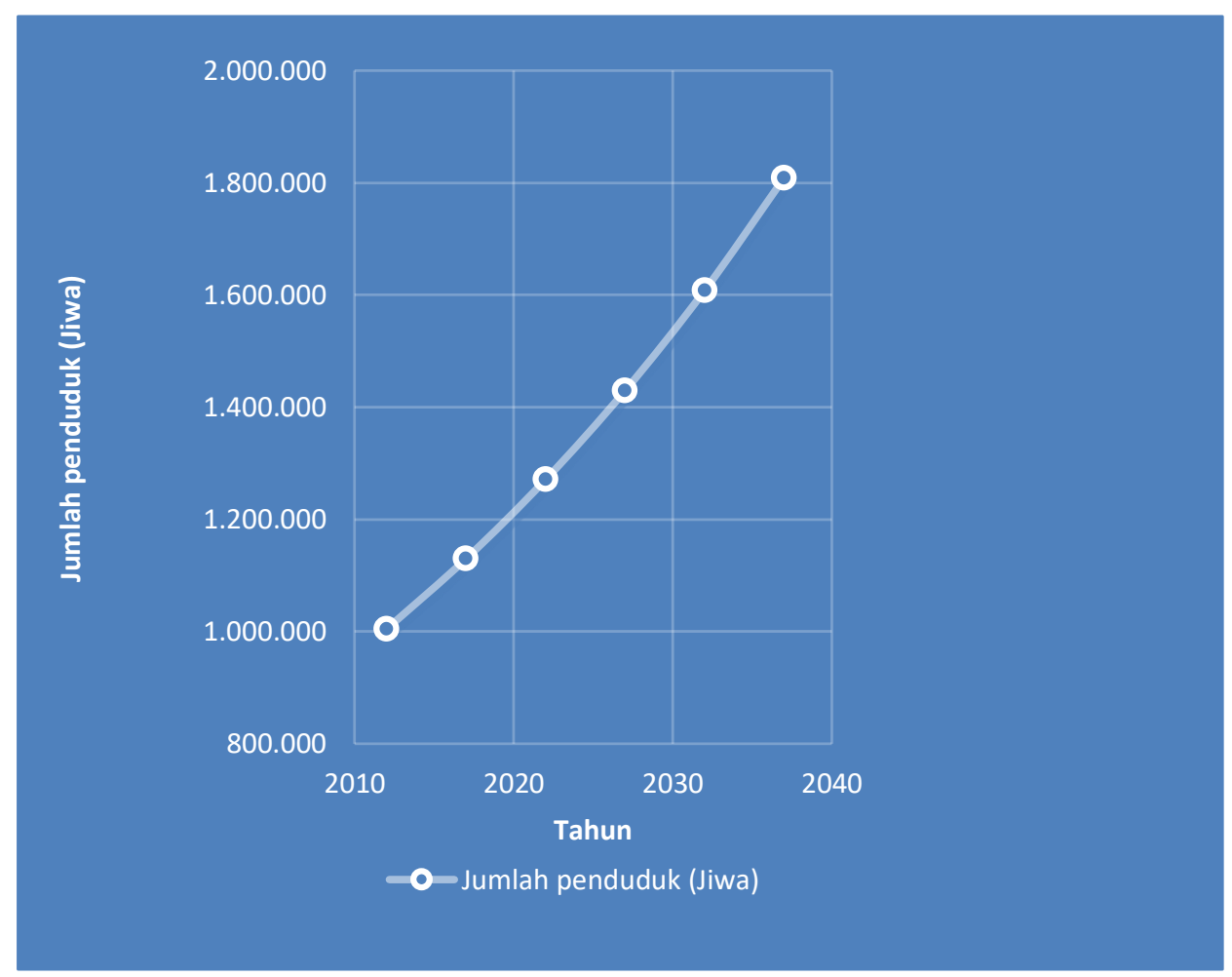

Gambar 10. Laju Pertumbuhan Penduduk Kota Bogor

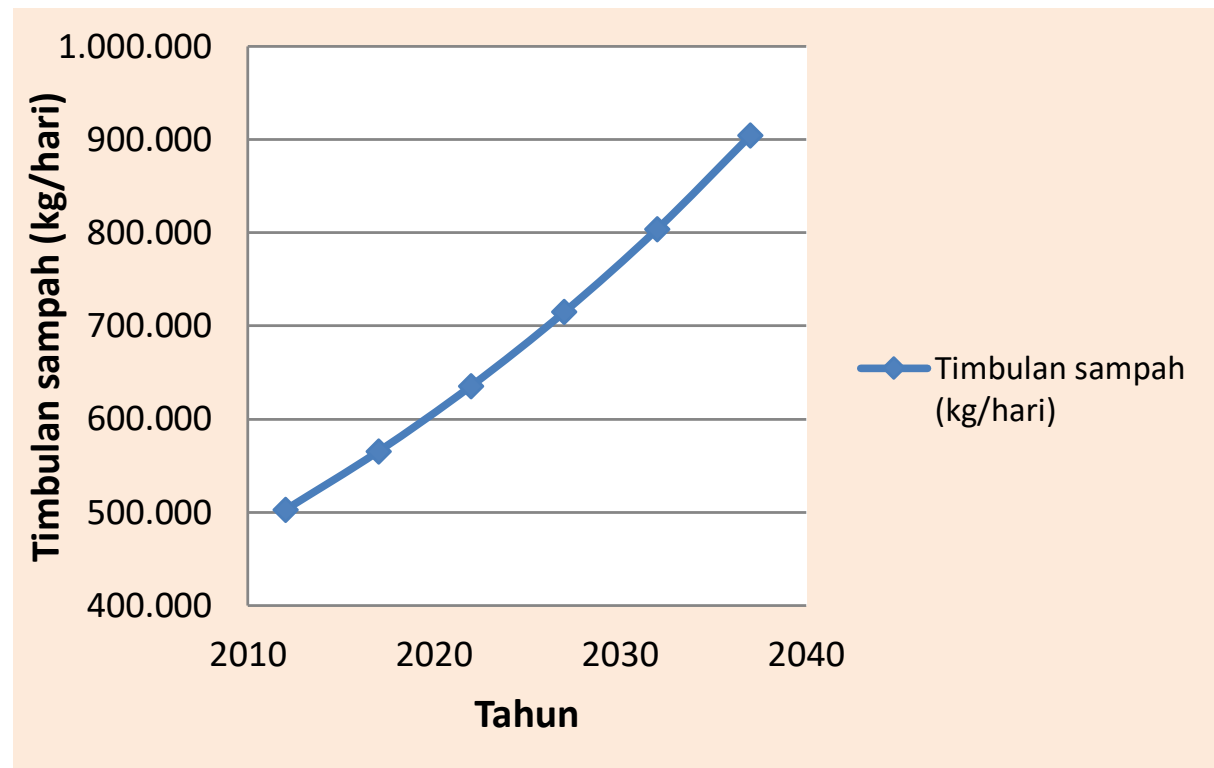

Gambar 11. Laju Timbulan Sampah Kota Bogor 
Walaupun Indonesia telah memiliki gerakan peduli sampah yang diperingati setiap tanggal 21 Februari sebagai "Hari Peduli Sampah Nasional", akan tetapi persoalan timbulan sampah terus semakin menjadi. Laju timbulan sampah telah mengkhawatirkan dikarenakan keterbatasan lahan yang dapat dioperasikan sebagai TPA. Untuk mengatasi persoalan ini pemerintah menetapkan Peraturan Presiden Nomor 97 tahun 2017 tentang tentang Kebijakan dan Strategi Nasional (Jaktranas) Pengelolaan Sampah Rumah Tangga dan Sampah Sejenis Sampah Rumah Tangga.

Dengan diberlakukannya

Peraturan Presiden Nomor 97 tahun 2017 maka diharapkan bahwa pada tahun 2025 akan terjadi penurunan bobot atau volume sampah yang masuk ke TPA sebesar 30\%. Meski tahun 2025 telah dicanangkan sebagai permulaan tahun "Indonesia Bersih Sampah" (Kementerian Lingkungan Hidup dan kehutanan 2018), telah disadari bahwa mengandalkan TPA 3R (reduce, reuse, recycle) tidak mampu menyelesaikan persoalan sampah yang ada. Peningkatan laju timbulan sampah adalah seirama dengan laju pertumbuhan populasi sebagaimana terlihat pada Gambar 10 dan 11 untuk permasalahan sampah yang terjadi di Kota Bogor. Seperti tampak pada kedua gambar tersebut untuk Kota bogor pada tahun 2025 jumlah penduduk yang ada diperkirakan mencapai 1,3 juta jiwa dengan timbulan sampah sekitar 670 ton/hari.

Guna mengatasi persolan sampah domestik yang kian pelik, khususnya persoalan sampah di kota besar, pemerintah menetapkan Peraturan Presiden Nomor 35 tahun 2018 tentang Percepatan Pembangunan Instalasi Pengolah Sampah Menjadi Energi Listrik Berbasis Teknologi Ramah Lingkungan. Dengan peraturan tersebut maka teknologi termal dalam pengolahan sampah domestik menjadi daya ungkit dalam menekan penurunan materi sampah yang di timbun dalam TPA. Terdapat dua belas kota besar di Indonesia yang menjadi loka utama penerapan teknologi termal tersebut. Pada saat ini Badan Pengkajian dan Penerapan Teknologi (BPPT) bekerja sama dengan Pemerintah Provinsi DKI serta Pemeritah Kota Bekasi sedang melaksanakan pilot project teknologi termal tersebut di TPST Bantar Gebang Bekasi untuk mengolah sampah dengan kapasitas 50 ton/hari untuk menghasilkan listrik dengan daya 400 kW. Kesangkilan (efficiency) pengubahan nilai kalor sampah menjadi listrik sangat dipengaruhi oleh karakteristik sampah yang diumpankan ke dalam unit termal. Biasanya sampah padat domestik memiliki nilai kalor sekitar 1.000 $\mathrm{kkal} / \mathrm{kg}$. sedangkan untuk keperluan umpan unit termal memerlukan nilai kalor setidaknya dalam kisaran $4.000-6.000$ $\mathrm{kkal} / \mathrm{kg}$. Perlakukan pendahuluan terhadap sampah padat menjadi pellet dapat meningkatkan nilai kalor sampah padat domestik hingga $8.000 \mathrm{kkal} / \mathrm{kg}$ dengan komposisi limbah organik sebesar 45\% (Dianda et al. 2018). Pada Gambar 12 disajikan karakteristik sampah Kota Bogor yang dikirim ke TPA Galuga. 


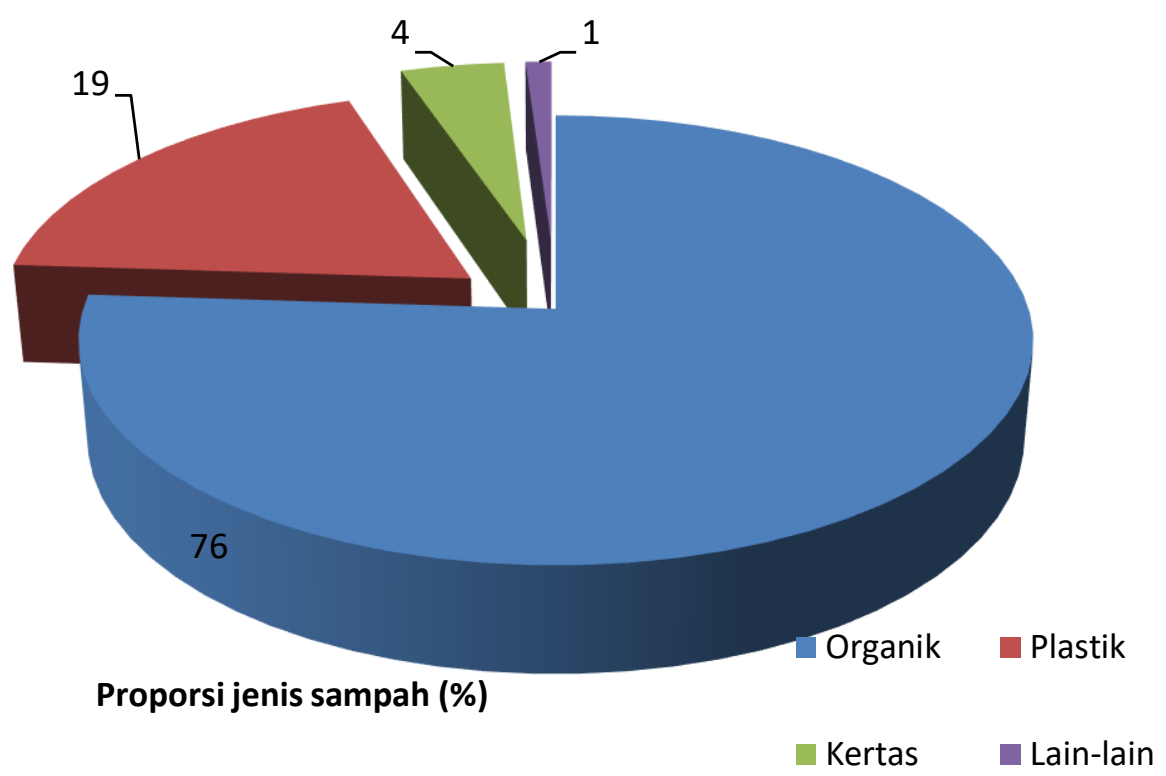

Gambar 12. Karakteristik Sampah TPA Galuga

Sesuai dengan peraturan
yang berlaku air lindi yang
dihasikan oleh TPA harus diolah
melalui instalasi pengolahan air
limbah (IPAL) dan wajib memenuhi
baku mutu yang terdapat dalam
Peraturan Menteri Lingkungan
Hidup dan Kehutanan Nomor 59
Tahun 2016 tentang Baku Mutu
Lindi Bagi Usaha dan/atau Kegiatan
Tempat Pemrosesan Akhir

Sampah. Terdapat 7 (tujuh) parameter yaitu $\mathrm{pH}, \mathrm{BOD}, \mathrm{COD}$, TSS (total suspended solid), total nitrogen ( $\mathrm{N}$-total) serta dua logam berat yakni merkuri $(\mathrm{Hg})$ dan kadmium (Cd). Nilai ambang batas untuk ketujuh parameter tersebut disajikan pada Tabel 3. Hasil pengukuran lapangan serta hasil uji laboratorium terhadap sampel tanah dan air disajikan pada Tabel 4 dan Tabel 5. 
Tabel 3. Baku mutu lindi menurut PermenLHK Nomor 59/2016

\begin{tabular}{|l|c|c|}
\hline \multirow{2}{*}{ Parameter } & \multicolumn{2}{c|}{ Kadar Paling Tinggi } \\
\cline { 2 - 3 } & Nilai & Satuan \\
\hline $\mathrm{pH}$ & $6-9$ & - \\
\hline BOD & 150 & $\mathrm{mg} / \mathrm{L}$ \\
\hline COD & 300 & $\mathrm{mg} / \mathrm{L}$ \\
\hline TSS & 100 & $\mathrm{mg} / \mathrm{L}$ \\
\hline N Total & 60 & $\mathrm{mg} / \mathrm{L}$ \\
\hline Merkuri & 0,005 & $\mathrm{mg} / \mathrm{L}$ \\
\hline Kadmium & 0,1 & $\mathrm{mg} / \mathrm{L}$ \\
\hline
\end{tabular}

Tabel 4. Hasil penetapan mutu lindi TPA Galuga berdasarkan uji laboratorium

\begin{tabular}{|c|c|c|c|c|c|c|}
\hline \multirow{2}{*}{ Sampel } & \multicolumn{4}{|c|}{ Beban cemaran (mg/L) } & \multirow[b]{2}{*}{$\mathrm{pH}$} & \multirow[b]{2}{*}{$\begin{array}{l}\text { Suhb } \\
\left({ }^{\circ} \mathrm{C}\right)\end{array}$} \\
\hline & COD & $\mathrm{BOD}$ & DO & Klorin bebas & & \\
\hline Inlet IPAL & 486 & 215 & 8,8 & 0,97 & 7,86 & 33,1 \\
\hline Outlet IPAL & 432 & 178 & 8,7 & 0,65 & 9,02 & 28,5 \\
\hline Badan air sebelum TPA & 180 & 163 & 6,3 & 0,99 & 8,30 & 32,4 \\
\hline Badan air setelah TPA & 384 & 1886 & 3,0 & 0,23 & 8,88 & 30,4 \\
\hline
\end{tabular}

Tabel 5. Hasil penetapan konsentrasi logam berat pada sampel air dan tanah

\begin{tabular}{l|c|c|c|c|c|c}
\hline \multirow{2}{*}{ Sampel } & \multicolumn{5}{|c|}{ Konsentrasi logam (ppm)* } \\
\cline { 2 - 7 } & $\mathrm{Co}$ & $\mathrm{Cu}$ & $\mathrm{Fe}$ & $\mathrm{Mn}$ & $\mathrm{Pb}$ & $\mathrm{Zn}$ \\
\hline \hline Inlet IPAL & $N D$ & $N D$ & 4,238 & 0,536 & $N D$ & 0,529 \\
Outlet IPAL & $N D$ & $N D$ & 0,984 & 0,447 & $N D$ & 0,148 \\
Badan air sebelum TPA & $N D$ & $N D$ & 4,437 & 3,025 & $N D$ & 0,611 \\
Badan air setelah TPA & $N D$ & 0,035 & $N D$ & $N D$ & $N D$ & 0,009 \\
Tanah & $N D$ & 0,084 & 8,396 & 1,096 & $N D$ & 1,414 \\
\hline
\end{tabular}

${ }^{{ }^{*} \mathrm{ND}}=$ not detected (tidak terukur karena konsentrasi logam berat di bawah batas deteksi metode pengukuran yang digunakan) 
Menyimak Tabel 4 di atas tampak bahwa kinerja IPAL TPA Galuga masih belum memiliki kinerja yang memadai. Kesangkilan (efficiency) IPAL dalam menurunkan kebutuhan oksigen kimiawi (chemical oxygen demand atau COD) hanya $11 \%$, yakni dari konsentrasi 486 menjadi $432 \mathrm{mg} / \mathrm{L}$ yang masih di atas ambang batas maksimum menurut PermenLHK 59/2016, yaitu 300 $\mathrm{mg} / \mathrm{L}$. Demikian pula kesangkilan dalam menurunkan kebutuhan oksigen biologik (biological oxygen demand atau BOD) yang hanya $17 \%$, yakni berkurang dari 215 menjadi $178 \mathrm{mg} / \mathrm{L}$. Nilai ini juga masih di atas ambang baku mutu yang ditetapkan yaitu tidak lebih dari $150 \mathrm{mg} / \mathrm{L}$. Data lainnya yang tidak lazim adalah nilai BOD yang melebihi COD untuk sampel badan air setelah TPA serta nilai oksigen terlarut (dissolved oxygen atau DO) untuk inlet IPAL dan outlet IPAL yang nilainya di atas konsentrasi oksigen terlarut jenuh dalam air pada kondisi ambient, yakni tidak lebih dari $8 \mathrm{mg} / \mathrm{L}$.

Peningkatan konsentrasi COD sebesar $213 \%$ untuk sampel badan air sebelum TPA, $180 \mathrm{mg} / \mathrm{L}$, menjadi $384 \mathrm{mg} / \mathrm{L}$ untuk sampel badan air setelah TPA mengindikasikan adanya sumbangan cemaran. Belum dapat dipastikan apakah peningkatan tersebut karena sumbangan effluent lindi TPA Galuga ataukah disebabkan karena buangan limbah domestik penduduk yang tinggal di sekitar TPA Galuga. Hal ini perlu dipastikan melalui verifikasi lapangan mengingat bahwa pernah terjadi rembesan parit atau kanal air lindi sehingga mencemari lingkungan akibat tidak optimalnya sistem IPAL di TPA Galuga
(Purwanti 2014, Hifdziyah 2011). Untuk mutu tanah hingga saat ini belum ada peraturan terkait dengan kegiatan yang terdapat pada TPA. Namun untuk keperluan Analisis Mengenai Dampak Lingkungan (AMDAL) maupun Analisis Risiko Lingkungan digunakan Peraturan Pemerintah Nomor 150 Tahun 2000 tentang Pengendalian Kerusakan Tanah untuk Produksi Biomassa serta Peraturan Menteri Lingkungan Hidup Nomor 7 Tahun 2006 tentang Tata Cara Pengukuran Kriteria Baku Kerusakan Tanah untuk Produksi Biomassa.

\section{KESIMPULAN}

Dari hasil kunjungan lapang ke tempat pemrosesan akhir (TPA) sampah Galuga serta PT Prasadha Pamunah Limbah Industri (PPLi) dapat disimpulkan serta disarankan hal-hal berikut:

a. Bobot harian sampah domestik Pemerintah Kota Bogor dan Pemerintah kabupaten Bogor secara bersama-sama yang ditempatkan pada TPA Galuga berada dalan kisaran $1.000-1.100$ ton/hari

b. Pemilahan sampah telah dilakukan sejak sampah ditempatkan pada tempat penampungan sementara (TPS) sampai dengan TPA

c. Teknologi TPA Galuga masih mencerminkan sistem pembuangan sampah open dumping sehingga masih menimbulkan persoalan bau serta lalat 
d. Proses pemilahan oleh pemulung serta beropersinya fasilitas pengomposan tidak mampu menyelesaikan persoalan peningkatan volume sampah yang diolah pada TPA Galuga

e. Ke depan penerapan teknologi pembangkit listrik berbasis sampah (PLTSa) perlu dipertimbangkan oleh Pemerintah Kota Bogor dan Kabupaten Bogor untuk mengantasipasi volume sampah yang terus bertambah

f. Operasi instalasi pengolahan air limbah (IPAL) TPA Galuga masih belum optimal karena melampaui baku mutu PermenLHK Nomor 59/2016, khususnya untuk parameter BOD dan COD.

\section{DAFTAR PUSTAKA}

\section{Afifah A. 2018. Kajian Pengolahan Limbah Padat di Tempat Pembuangan Akhir (TPA) Galuga dan PT Prasadha Pamunah Limbah Industri (PPLi). Sekolah Pascasarjana. Departemen Teknologi Industri Pertanian. Fakultas Teknologi Pertanian. Institut Pertanian Bogor}

Chaerul M., M. Tanaka \& A.V. Shekdar. 2007. Municipal solid waste management in Indonesia: status and the strategic actions. Journal of the Faculty of Environmental Science and Technology. Vol.12(1):41-49

Damanhuri E. \& T. Padmi. 2010. Diktat Kuliah Pengelolaan
Sampah. Program Studi Teknik Lingkungan. Fakultas Teknik Sipil dan Lingkungan. Institut Teknologi Bandung

Desmawati B. 2010. Pengaruh Tempat Pembuangan Akhir (TPA) Terhadap Kualitas Air Sumur, Kesehatan dan Sosial Ekonomi Masyarakat di Sekitar TPA Galuga. Dokumen Tesis. Sekolah Pasca Sarjana. Institut Pertanian Bogor

Dianda P., Mahidin \& E. Munawar. 2018. Production and characterization refuse derived fuel (RDF) from high organic and mositure contents of municipal solid waste (MSW). IOP Conference Series: Materials Science and Engineering Vol.334. IOP Publishing Ltd.

Hifdziyah L. 2011. Analisis Penurunan Kualitas Lingkungan di Sekitar Tempat Pembuangan Akhir Sampah Galuga Kabupaten Bogor Jawa Barat. Departemen Ekonomi Sumberdaya dan Lingkungan. Fakultas Ekonomi dan Manajemen. Institut Pertanian Bogor

Indrasti N.S., A. Y. Aryanto \& Y. Suprayogi. 2019. Modul Praktikum Teknologi Limbah Padat dan B3. Divisi Teknik dan Manajemen Lingkungan Industri. Departemen Teknologi Industri Pertanian. Fakultas Teknologi Pertanian. Institut Pertanian Bogor

Kementerian Lingkungan Hidup dan Kehutanan. 2018. KLHK Sosialisasikan Pengelolaan Sampah Mulai dari Sumbernya URL:

http://ppid.menlhk.go.id/siaran 
_pers/browse/1150

[Online, diunduh pada 2 Maret 2019]

Peraturan Menteri Dalam Negeri Nomor 33 Tahun 2010 tentang Pedoman Pengelolaan Sampah

Peraturan Menteri Lingkungan Hidup dan Kehutanan Nomor 59 Tahun 2016 tentang Baku Mutu Lindi Bagi Usaha dan/atau Kegiatan Tempat Pemrosesan Akhir Sampah

Peraturan Presiden Nomor 97 tahun 2017 tentang tentang Kebijakan dan Strategi Nasional (Jaktranas) Pengelolaan Sampah Rumah Tangga dan Sampah Sejenis Sampah Rumah Tangga

Purba F. 2016. Pengelolaan Limbah Domestik di Tempat Pembuangan Akhir (TPA)
Galuga Bogor. Program Studi Teknologi Industri Pertanian. Sekolah Pascasarjana. Institut Pertanian Bogor

Purwanti H. 2014. Kajian dampak saluran lindi terhadap lingkungan ditinjau dari aspek pengoperasian TPA Galuga. Jurnal Teknologi Vol.1(25):5769

Undang-Undang Nomor 18 tahun 2008 tentang Pengelolaan Sampah

Yusuf M.A. 2017. Laporan Praktikum Pengelolaan Limbah Domestik di Tempat Pembuangan Akhir (TPA) Galuga Bogor. Sekolah Pascasarjana. Departemen Teknologi Industri Pertanian. Fakultas Teknologi Pertanian. Institut Pertanian Bogor 